\title{
MOODLE Platform Evaluation in the Light of E-Learning Sites Standards from the Point of View of College of Basic Education Students in The Public Authority for Applied Education and Training in Kuwait
}

\author{
Dr. Abdul Aziz Dakhil Al-Anzi \\ College of Basic Education
}

The Public authority for applied Education and training in Kuwait

Received: January 2, 2021 Accepted: February 16, 2021 Published: March 5, 2021

doi:10.5296/ijld.v11i1.18379 URL: https://doi.org/10.5296/ijld.v11i1.18379

\begin{abstract}
The Study aimed at MOODLE platform evaluating educational website standards through the student's viewpoints who study in the Faculty of Basic Education in the Public Authority for Applied Education and Training in Kuwait. The study used the descriptive survey method. To evaluate MOODLE educational platform, the researchers developed a list of standards consisted of (30) items divided into five domains. The randomly selected study sample consisted of (392) students. The results showed that the evaluation of MOODLE educational platform in light of E-learning sites standards came with a medium degree, they are available to an acceptable degree, and the mean of the tool as a whole was (3.55) by $71 \%$, and the domains rank in order were; the domain of vitality came first with a mean of (3.75) by $74 \%$, while the educational value domain came second with (3.70) by $74 \%$. In contrast, the content domain came third with a mean of (3.48) by $69.6 \%$, while the usage characteristics domain came with (3.47) by $69.4 \%$, where the usage domain came last with a mean of (3.46) by $69.2 \%$. Results also revealed no statistically significant differences $(\alpha=0.05)$ attributed to the effect of Gender in all domains and the full degree.
\end{abstract}

Keywords: MOODLE Platform, E-learning, Standards, College of Basic Education, The Public Authority for Applied Education and Training, Kuwait 


\section{Introduction}

The Curriculum is one of the most vital and most influential tools in changing the educational process in the contemporary world because society sees the Curriculum as a first force in shaping the student entity and its aspirations and future hopes throughout his life, as it represents the central pillar in the refinement of the student's personality. The development of the human aspects of its relations with others is also a mirror reflecting society's reality, including values, customs, traditions, and human and social relations. Therefore, many curriculum scientists believe that the development of the Curriculum and the comprehensive reform of educational systems is necessary to be renewed from time to time, given the changing events, circumstances surrounding and external influences and the developments of the technological age, which has been characterized by a widespread of technology and networks of websites.

Online learning sites are an online environment rich in learning elements, allowing learners to interact with educational materials in their various forms, navigate them freely, help them take responsibility while learning, and learners become more willing to learn to own them. The government's ability to provide services to the neediest and provide them with the local police services is also a source of support for the government's ability to provide services to the local police. Educational sites allow learners to engage with each other through modern communication tools, facilitate the exchange of experiences, create knowledge, and eliminate learners' isolation in learning through online courses published through educational websites such as Moodle and other educational websites Sites (King \& Leroy, 2014).

It is necessary to achieve flexibility in the structure of the electronic Curriculum to make changes that concern the learner and society, science, technology, Education, the local environment, and others require that the Curriculum understand what is happening from these changes and be able to develop in keeping with them without shaking their structure or need to rebuild again. This flexibility is not achieved at the required level unless established by those who choose the Curriculum's experience. For example, suppose curriculum organizers believe that this flexibility should be completed by providing the learner opportunities to choose from several courses. In that case, it depends on the abundance of the experience supplied by those who prefer the Curriculum's expertise to do so. Flexibility requires that the available experiences in the Curriculum - and this is the task of his choice - allow the organization of these experiences in several levels through which the curriculum organizers take into account the individual differences between learners, the diversity in teaching methods, and educational activity, and the opening of channels of communication between different aspects of the Curriculum so that It becomes an integrated educational system (Shawk, 2001). In addition to choosing the best educational website to publish e-university courses to achieve the educational goal of learning from those courses.

To achieve the objectives of the e-curriculum, courses and websites must be subject to a process of evaluation and analysis from time to time to detect and develop weaknesses.

It plays an essential role in providing accurate Information to educate decision-makers about the effectiveness of the process as a whole, enabling them to judge the effectiveness of 
Education with its various elements and components so that it can make its own decisions and identify its strategies for innovation, improvement, and development in the system. Educational, guiding decision-makers to draw scientific lines (Hammad, 2011; Hasan, 2014)

Similarly, the calendar of websites and their services reflects their performance, gives an honest picture of them, and institutions have begun to develop standards that can be used in the calendar of websites or rely on clear criteria set by scientific bodies (Hassanein, 2009).

Therefore, in the current study, I will evaluate Moodle in the light of the standards of the educational websites from the point of view of students of educational technology at the Faculty of Basic Education in Kuwait, given the importance of these sites to the learning process and the benefits it offers. E-courses posted on these sites for students, faculty, administrators, and generally for the educational institution

\section{Theoretical Framework}

\subsection{Educational Sites (need - interactive environment - building foundations)}

In recent years, the number of educational websites belonging to educational institutions has increased, and activity continues to evolve. It provides, and Information on websites is cumulative and increased, unlike Information published in traditional forms of books, articles, periodicals, etc. (Najjar and Hasuna, 2016).

When the network education system is settled in an educational institution, the most important thing you seek is to create a database in the computer system, whether academic, administrative, or legal. Other types of Information that are related to the objectives of the educational process and its management over networks and are Information on demand for the learner, who can benefit from it in time of need without reviewing the teacher or institution, depending on his condition and access to ready answers to his or her questions, or access to the assistance he needs without checking the teacher or institution (Abu Hassan, 2010).

The computerization of the educational Curriculum is a pioneering step for educational institutions, where cadres and material and human possibilities harness them, however, after years of teaching, the content of these curricula shows some strengths and weaknesses, and the muscles must be strengthened. The failings must be addressed continuously by evaluating this Curriculum and making the necessary adjustments (Al-Mutairi, 1429H).

Websites are rich learning resources with multiple multimedia contents, which can be used numerous times and in more than one place (Liu, 2007), and websites are some educational pages and digital resources in web-based environments to provide web-based web sites Learners learn flex by sailing in a non-linear way to suit the needs of learners (Clewley, et al., 2011). The website can be defined as a web tool that transmits experiences and knowledge, refines skills, meets the Curriculum's objectives, and includes reusable elements. Hadjerrouit, 2010), McKim et al. (McKimm et al., 2010) noted that educational sites are a system that provides for online scientific content, discussion forums, e-mail, video conferencing, live lectures, printed materials (fixed pages), as well as sites contain links Hyperbole allows 
access to a tremendous amount of Information.

Interaction with the educational software added on the website is done by navigating different styles and navigating within the content. Selecting the navigation style is one of the most essential pillars of the design to impact learners' movement and movement in the sites significantly. Individual cognitive differences and reliability help raise their academic level (Hindawi, 2005).

The united nations are the only country in the world that has been able to overcome the crisis. Many researchers studied educational sites' effectiveness that achieved educational outcomes and gave students different learning aspects such as Abu Jahajuh and Harb, 2013; Khalifa, 2008; Hadjerrouit, 2010; Bhatia, 2011). This interaction and the achievement of the desired objectives are since sites rely on simultaneous and asynchronous interaction tools, through which opinions are built, and feedback and calendar are provided (Hopkins, 2010).

Educational sites are a form of e-learning, employing communication technology to support the interaction of all kinds, providing learning resources anywhere and anytime (King \& Leroy, 2014), and developing learners' abilities for self-reliance, self-confidence, self-guidance, and endurance. Responsibility (Riel, 2001) is achieved by producing learning resources for educational sites to suit learners' needs and abilities, learning and cognitive methods. The sites rely on different super media forms to provide learning elements to learners (Ahmed and Said, 2014).

When designing, educational sites adhere to their production standards that achieve efficiency and reach goals. The sites take into account the methods and educational assets in the design to build an integrated and interactive learning environment, allowing the learner to engage in educational activities through the Internet, and contain the sites Educational on Detailed explanations of educational content, in a variety of forms, lead to the building of knowledge and high-quality outcomes among learners (Al-Roobaea, et al., 20131; Trujillo, 2008).

Educational sites are based on scientific and intellectual theory, which contribute to the diversity of educational content and present it in interactive ways according to individual differences between learners (Burgess, 2001). This is due to the learner's changing Role at the center of the educational process from the Role of a future of Information to a knowledge seeker (Knowlton, 2000).

\subsection{The Importance of Published e-Courses}

E-learning has created different forms to develop the educational process after the impact of technological innovations on Education. With the spread of this technology, the state of e-learning design needs to be changed in proportion to the new technology to increase its effectiveness, as well as the creation of courses Web-based electronics need to be changed in design format to suit the new generation of the web, leading to a new educational renaissance (Amasha, 2009).

Brianl (2001) noted that Internet technology automatically serves educational administrative work, which increases the Use of time and effort, facilitates tasks, and qualitatively improves 
educational programs at all levels. Educational means must be developed, the learner's needs and needs are supported, and management is one factor designing any electronic program. It is also considered the central element of the work of any e-learning program. It corresponds to the needs and appropriate design, which is the most critical stage of planning for e-learning, and therefore comes in terms of the importance of the final stages of development, leadership, operation based on experience and access to feedback, and must cover some or all administrative tasks and organizational, where the Role of management and support for the application, where a team must be formed to develop e-learning.

Saleh (2005) considers the need to measure the quality of the e-learning course about the structure and sequence of activities of the content, the strategies of the Education used, the objectives of the course, the interactive, the feedback, the opportunities of application, performance presentation, measurement of the effectiveness of the course, among others, in addition to aspects Educational and educational related to screen design and interface application. And choose the most appropriate web educational site to publish associated files and programs, computerized educational materials, and e-books that form a link between the student and the teacher, which enables the student to download and interact with the files of educational materials by asking questions and questions about the topic of learning, and the opportunity for his colleagues or teachers to answer those questions (Najjar and Hassouna, 2016).

This phase needs the characteristics of the positive educational environment that characterizes the e-courses, and was identified by Al-Ghribi $(1430 \mathrm{H}$, p. $45-46)$ as follows:

1). The hall's physical environment should be comforTable, attractive, equipped with the necessary educational resources, materials, and tools, and organized in a way that provides students with opportunities for individual learning and group learning.

2). It is not a safe environment in which the learner does not feel intimidated, anxious or threatened.

3). Take into account the learner and ensure his learning and growth.

4). The environment should motivate every learner to make every effort possible to learn, engage the learner with learning, engage in it, be patient with it, and exert its full energy to acquire knowledge and knowledge.

5). The environment is participatory and the learning process is meant to be a participatory process in which teachers and students contribute. The teacher's Role is to be the Role of the mentor and not the source of Information.

6). The environment is based on self-control or self-management, which means that students in this environment learn to control their behavior and behaviors, in a way that is easy to learn and develop.

Al-Shahrani (1430 Ah) referred to the course content to develop the scientific material that constitutes the content of the Curriculum and determines the sequence of subjects to be studied by students from a written scientific material accompanied by vocabulary provided 
using multimedia. The scientific material can be in the form of readings and duties Lectures and instructions for recollection, a list of terms, notes, etc., consisting of visual and audio material, images and simulations prepared by computer, and organizes the subjects of the Curriculum in the form of files and folders with links that lead the student to the different courses of the Curriculum.

Al-Jarf (2004) confirmed that the electronic course increases interaction and communication between teachers and students. The student has a positive and active role in the electronic circuit, where he contributes to the preparation of the scientific material of the system, and expresses his opinion on it, and comments on what other students have provided, and allows the electronic course Internet-based opportunity for students to communicate you with a tremendous amount of Information. E-learning programs that replace the traditional course are flexible and offer opportunities for enrichment and review. The teacher can use multiple teaching methods such as simulation, exploration learning, experience-based learning, and individual therapy. If he uses well-designed training and tests, it will diagnose the difficulties that prevent students from mastering a particular point and provide them with additional or alternative explanations and practice until they master that point. It makes it easier for the teacher to correct tests and assignments and gives him with statistics on students' achievement and improvement as individuals and as a group. Parents can see the scientific material provided in the online course and the results of their children.

\subsection{Moodle Educational Site}

Multiple sites have spread through the world wide web, educational sites have become available to everyone, and the learner was able anywhere to access and learn from the educational material, and use the tools and services of the sites in the educational process, and from the famous educational sites in The publication of university courses, general courses and other services Moodle, the subject of the current Study, is a free website open to all, a use of Moodle to place a course on the platform by creating the time and its management, managing student records, and building The main entrances of the study, types of educational resources and how to link them to the system, designing and managing a forum for a decision, sending and receiving assignments and tasks, building the schedule of the course and following up the activities of students, ways of communicating with students and building referendums, methods of evaluation and building tests. Web-based learning design models are useful if well designed because good design ensures that students' interest is maintained and their motivation to continue learning. The poor design causes a large number of students to drop out, and therefore the percentage of students completing their studies is reduced. The course, and then on student learning outcomes, educational literature is full of many educational design models characterized by quality and motivate students to learn (Cahalan, 2000; Jackson \& Helms, 2008).

Moodle is a course management system, an education management system, and an educational content management system. It contains tools to develop educational activities on it. Everyone has the right to download, install, use, modify and distribute free of charge, and is available on the Internet, and is generally considered easy to install. Use and even 
development, including activity modules such as forums, sources, magazines, tests, tasks. And so on. It is currently used by thousands of educational institutions around the world to find and produce online courses and to support traditional courses, Moodle is built on academic grounds, features continuous and fast updates, and can be used through different unrestricted browsers (Afana, Habeb, \& Saliha, 2014).

Moodle achieves a number of advantages in Education as it is an appropriate tool for building electronic curricula (compilation, tab, presentation), and there is a forum where the teacher discusses topics related to the learning process, and takes care of the module to create several pages that display the content or part of it, and can at the end of each A page to add a question or link to a next page or previous or other, and gives an excellent opportunity for the learner to send his duties and tasks assigned by the teacher and upload them to the sites in different formats in order to present it to the teacher, and helps Moodle to follow the learner from the beginning of his entry to the system until his exit with the availability of a report for each learner, In addition, the teacher can make discussion groups according to tasks and educational level or the system is configured, and the system has chat rooms and forums for academic dialogue, in addition to including various tools for evaluation (tasks, activities, tests, tests), correction and registration of grades are done automatically. According to the teacher's criteria for multiple, right, wrong or other testing tests (Abdul Majid, 2008; Saba, 2005).

Many studies have indicated the effectiveness and direction of students for Moodle and these studies have been interested in employing Moodle in the learning process, acquiring technological skills, designing and point of an electronic course to develop Moodle's skills and impact on achievement, as well as developing Mathematical thinking and other thinking skills, and students' preference to use Moodle as a study site (Mohammed, 2011; Dahlan, 2012; Ashour, 2009; Bremer \& Bryant, 2005).

\subsection{Website Evaluation Criteria}

Given the importance of the Role that websites play in Education, and the high reliance on them, there is an increasing need to conduct continuous assessments to determine the effectiveness of those sites, and to decide on their quality and improvement, as the calendar helps to detect strengths and weaknesses in the sites, and to find solutions. For weaknesses, strengthening strengths, by seeking to set standards in the light of educational websites (Al-Roobaea, etal., 2013; Andrews, 2001).

Many studies have developed standards for evaluating educational websites from different perspectives, such as studying (Mohammed, 2014; Omari, 2014; Film ban, 2012; Hasan, 2014). Educational standards are guidelines for setting a standard for the site's quality and educational course, and obtaining expectations. High-quality educational output through the website and the course in their elements, and this step can provide the basis for building the Curriculum as guiding tools for teachers in collecting raw educational materials and designing the Curriculum, and improving the quality of the educational process. The standards work as a guide for teachers, educational leaders, and decision-makers to enhance and strengthen the educational process and enhance methodological frameworks, continuous evaluation, and educational institutional performance (Al-Khaznadar, 2006). In addition to 
developing websites and taking into account their weaknesses.

Several studies have revealed a deficiency in the organization and structure of educational sites (Hasan, 2014) and that (69\%) Educational websites with vulnerabilities related to the usability (Al-Roobaea, et al., 2013; Andrews, 2001), the Study of Ashour and Ben Abdessalam (Achour \& Ben Abdesslam, 2012) indicated that (70\%) From the sites did not specify the general Information of their existence, and the lack of most sites educational standards, utilities and language materials, while Mr. (2009) showed that the availability of educational standards in educational sites for educational technology of Education was (48\%). Study (Najjar and Hasuna, 2016) on the availability of calendar criteria at the Educational Readout site to an average degree, where the overall average availability score (08.2) was $69.5 \%$.

To conduct the evaluation process, standards must be established for evaluation, and standards are what the learner should know, the mental and practical skills he or she can perform, and the values and behaviors he acquires. The standard levels of each element of courses or curricula must be available from philosophy, objectives, content, activities, education methods, learning, sources of knowledge, educational media and evaluation (Al-Ghamdi, 2009). Al-Luqani and Sentences (2003:279) defined the criteria as "opinions that are the result of many psychological, social, scientific and educational dimensions, which can be applied through their application ".

An assessment of the location of other processes in the course is made through the criteria, which describe the foundations in which the course is built, or phrases that reflect what knowledge, Information and skills a student should know, and determine the level at which he or she should be reached in skills and processes, and what he acquires. Behaviors in a specific learning period, in specific areas of knowledge, and standards are also used to judge quality. Accordingly, the criteria for evaluating websites, their services and management of educational courses (Najjar and Hasuna, 2016) are determined.

The criteria can help students improve achievement in different subjects, identifying the skills performance levels that a student should be able to achieve, and correctly guiding the evaluation process by determining the learning outcomes that the student must achieve; Standards' is what all students should know and be able to do and do. Standard levels are a means of reform and improvement of Education (Mohammed and Abdul Azim, 2011).

Kozma (Kozma, 2003) noted that under different educational management systems around the world to change the practices of teachers and students within many e-learning, whether distance learning or through classrooms in these countries, and the Use of technical tools and resources that support students as they search for Information, design and publishing products, and learning through courses published across the sites. Hence, teachers build, build and provide advice, monitor the development and growth of these practices, which are widely used, and the development of the site by specialists and technicians. E-mail to spread the educational benefit to the university institution with its elements.

Accordingly, the evaluation process must be integrated and balanced with the teaching 
process. It must be well planned, as the World Encyclopedia of Educational Evaluation has made it clear that it is a systematic and structured process for data collection and interpretation of evidence, leading to student or programmer judgments and thus helping to clarify educational work and take appropriate measures (Wisker, 2000).

The criteria for evaluating educational websites have been numerous. Many studies and sources have outlined educational website calendar standards, and Hasan (2014) has set standards for evaluating educational sites (sailing, organizational intent, ease of Use and communication, design, Ahmed and Saeed (2014) used to learn outcomes, teaching and learning methods, course descriptions, multimedia, and student affairs as calibrated to assess the quality of e-courses. Al-Omari and Flaata (2014) used educational standards such as: objectives, content, activities, and technical standards, such as the interface of interaction, colors, interactive, and multimedia to design and evaluate a website, and Khalil (2008) identified the quality standards of the electronic courses in the rapporteur's reference. its Information, content design, multimedia, interactive control, modernity, contemporary, cost,

Schwier (Schwier, 2001) believes that content, target group, credibility, accuracy, objectivity, modernity, content, aesthetic, sailing and accessibility are among the most important standards of educational website calendar, and Bantjes and Cronje, 2000 has reached (59) standards and indicators. To evaluate educational sites, divided into seven categories: page design, multimedia, interaction and sailing, educational strategies, and ease of Use.

Based on the above, the researcher, after reviewing the literature and previous studies, designed a list of criteria consisting of five axes, which are derived from the paragraphs of the evaluation criteria: (axis of Use, axis of content, axis of educational value, axis of vitality, axis of characteristics of Use), the researcher noted that the Study the current one may be the first of its kind to evaluate Moodle in light of the standards of the educational websites in Kuwait.

\subsection{The Problem of Study and Its Questions}

The Use of educational websites in university institutions has become an urgent imperative. The researcher noted in the framework of her work the benefit to students and faculty at the university after the employment of Moodle in the learning process, and the spread of e-courses Activities, trainings, tests and other services provided by Moodle, this site, which seems to be the first Study of its kind in Kuwait, and the lack of studies after the researcher's knowledge that dealt with the evaluation of Moodle site in light of the criteria of educational websites, In this way, we will prepare a list of appropriate criteria for evaluating Moodle's website and identifying the views of students specializing in education technology at the university, so the study problem can be formulated in the following questions:

1-What is the degree of evaluation of Moodle in light of educational websites' standards from the point of view of students of educational technology in Kuwait?

2-Are there statistically significant differences $(==0.05)$ in Moodle's rating in light of educational websites' standards from the point of view of students of educational technology in Kuwait due to the Gender variable? 


\section{Macrothink}

\subsection{Study Objectives}

\section{The objectives of the Study are as follows:}

1- To know the degree of evaluation of Moodle in light of educational websites' standards from the point of view of students of educational technology in Kuwait.

2- Determining the degree of evaluation of Moodle in light of educational websites' standards from the point of view of students of educational technology in Kuwait due to the Gender variable (male, female).2.7 The Importance of Study.

The importance of the Study lies as follows:

1- Evaluation of Moodle site in light of the criteria to measure the degree of evaluation of the Model site from the point of view of students specializing in education technology at the university in Kuwait.

2- The Study may benefit researchers in highlighting the calendar of educational websites on an ongoing basis, especially the most widespread and the most widely used Moodle site and highlighting areas of strength and weakness to conduct a development process that suits education requirements and students' learning.

3- Moodle's learner site assessment may enhance self-learning and enhance its capabilities through learning and practice and facilitate the learning and learning process.

4- It may be useful for specialists, technicians and developers of the university curriculum to develop Moodle and other educational sites and establish educational programs and university electronic courses that help to develop and acquire students learning skills, and train teachers and qualify them to acquire skills and Information individually, Productivity, creativity, the ability to analyze and solve various problems.

\subsection{Study Terms}

Evaluation: "The process that determines the extent to which the objectives have already been achieved, a preventive therapeutic diagnostic process aimed at diagnosing situations, identifying problems and identifying obstacles in educational work to improve and develop it to achieve the desired goals" (Al-Omari, 2002:17).

Moodle: "An open-source learning management system designed on educational grounds to help trainers provide an electronic learning environment that can be used personally at the individual level and can serve university students", (32 Weaver, 2008).

-Criteria: "The test or frame of reference on which realistic performance is determined in the extent to be far away from references" (Sinebel, 2001: 52)

-Electronic course: "Multimedia electronic learning material, provided through the computer and the Internet, providing simultaneous and simultaneous interaction between students, both content, their peers, and their teachers" (Abu khtwa, 2010: 7). 


\subsection{Study Limits}

1- The Study was limited to conducting an assessment of Moodle in light of educational websites' standards.

2- The Study was limited to students of education technology at the Faculty of Basic Education in The Public Authority for Applied Education and Training in Kuwait, in the second semester 2020/2019.

\section{Literary Review}

\subsection{Previous Studies}

Studies related to the evaluation of educational websites including Moodle

Kahlan (Cahalan, 2000) conducted a study to design a graphical management-oriented model for Use within the online classroom. This element or application supports lecture procedures, question processes, and answers between students and students involved in the same thing remotely. To achieve the objectives of the Study, the theoretical descriptive approach was used, and the study tools were to analyses the needs and requirements of the situation, while at the same time this Study contained a comparative analysis of both the available and technical possibilities available and used by distance education organizations. The Study reached several conclusions, including: the result of the step with requirements and the stage of comparative analysis is the production of the regulatory interface for the beneficiary, the beneficiary has also evaluated the organizational model, and the model was evaluated for dealing across the web as a window for the electronic semester, and was tested using the original educational model.

Badr (2001) conducted a study aimed at designing the Web site according to educational bases, and studying its effectiveness in teaching the statistics unit to the students of the first grade of secondary school, and to achieve the objectives of the Study was used the experimental method, and the study tools were designed and published over the Internet using the software (Front Page 2000) for the company "Microsoft". The research sample consisted of (9) students from the first grade of secondary school in Saudi Arabia, and an educational test was applied to them tribally and after. The Study reached several conclusions, including: the effectiveness of using the Internet in teaching the statistics unit to first-grade high school students. The Study also recommended the need to pay attention to interactive applications because they are better than the regular pages that come close to being pages reviewed by the student.

Bremer \& Brayant, 2005, aimed to compare Blackboard and Moodle as an e-learning tool from a student point of view. The researcher used the descriptive Curriculum to interpret the results of students' responses to the questionnaire distributed to (20) students. The results showed that $80 \%$ of students preferred Moodle, while $20 \%$ preferred Blackboard.

Lamont (Lamont, 2008) conducted a study to identify the effectiveness of an electronic undergraduate teaching program from a student point of view. The Study used the method of content analysis where the content of the e-course was analyzed, especially about the delivery 
systems of learning material on the electronic course. The study results indicated that some strengths and weaknesses characterize the system of delivery of learning material on the website that offers the electronic course according to the perceptions of the students participating in this Study. The results indicated that students believe that the e-course designer's responsibility and the responsibility of the learner play an important role in judging the quality of the e-course provided to students .

Jackson \& Helms conducted a study to identify students' perceptions of the effectiveness of an e-learning program offered at the undergraduate level and the need for e-course management systems. To achieve the study's objectives, the descriptive method was used, the study tools were based on questionnaire swot, and the Study used analysis (SWOT) to analyze data collected from the study sample. The study sample consisted of 54 second-year students who were randomly selected from a US university. The Study reached several conclusions, including: the system of delivery of learning material on the website that provides the e-course was able to present the material according to the individual's abilities. There is a need to use e-course management systems that take into account the individual needs of students. The Study also recommended adopting management systems for electronic courses capable of providing and managing the material in educational sites.

The Sánchez-Santamaria study (et al.,2012) aimed to analyze and compare students' perceptions of the Use of Moodle platform in university education. The study sample consisted of (178) students studying Education and social sciences at the University of Castella La Mancha in Toledo, selected randomly. A five-pronged questionnaire and (118) paragraphs were prepared and distributed to the participating students to collect the data. The study results showed that students showed a high degree of satisfaction about the Use of the model platform and its benefits in university education and as indicated by students some obstacles such as training and technical problems.

The Study of Afana, Habayb and Saliha (2014) aimed to evaluate the experience of The National University of Success in employing the Moodle e-learning management system in the teacher training program at the Faculty of Educational Sciences, used the descriptive survey method. The researchers prepared the corresponding tool applied to (10) members of the Board Teaching supervisors of the training process, a questionnaire was distributed to a sample of (87) prepared specifically for Study to evaluate the experience from the point of view of the teachers. The results showed that the participation of educated teachers is uneven, but generally good. There is an awareness of the importance of using technology in teaching and learning. However, there are many challenges and difficulties faced by trainee teachers as their first experience, the most important of which was the lack of prior training on computer, and the lack of infrastructure within their homes and schools.

Nurkhamimi et al., 2016, aims to reveal a model platform's appropriateness to support open learning and distance learning among students and academics at the University of Sins, Malaysia. The study sample consisted of (18) students studying open learning and distance learning at the University of Saints four lecturers, all of whom answered the questionnaire prepared by the researcher to achieve the study objectives. The study results showed that 
despite great efforts in this field, the model platform is still used as a warehouse and warehouse for educational materials according to students' opinions. Academics also saw the importance of the Model platform as a promoter of learning and Education .

Al-Najjar and Hassouna Study (2016) aim to evaluate the educational site of The Ministry of Education and Higher Education in Palestine according to specific criteria, and to achieve this reached 6 main criteria, under which 74 indicators were included, appeared in the form of an electronic calendar form, applied on the site of The Educational Tributaries of Before 21 specialists in Education and information technology, the results revealed the availability of calendar criteria in the educational tributaries site to an average degree, where the overall average availability score (08.2) reached $69.5 \%$, and the availability of the site's reference and Information criterion to a large extent, and ranked first, by $82 \%$, and The multimedia standard was second, highly available, with a relative average of $81.3 \%$, while the site's electronic content standard ranked third, medium availability, and a relative weight of $73.3 \%$, achieved the standard of interface and screens of the site at an average level, with a relative weight of $68.6 \%$, and ranked Fourth, the standard of instruments of interaction and control of students was available with an average degree, with a relative weight of $65 \%$, and ranked fifth, and the standard of presentation patterns and learning theories, obtained the last rank, availability to a low degree, and a relative weight of $47 \%$, the Study recommended that the previous criteria should be observed when developing Educational sites.

\subsection{Related Studies}

Ashour Study (2009) aimed to identify Moodle's effectiveness in acquiring 3D design skills in students of the Faculty of Education Technology at the Islamic University. The researcher built an electronic course for the 3D design course and then uploaded it to the Model program and applied it to students, and used the researcher tools the Study, which is an educational test consisting of (30) questions divided on five skill axes by which the researcher measures the cognitive level of students, and a note card consisting of (25) paragraphs divided into five skill axes by which the researcher measures the performance level of the students. The researcher chose a mean sample of (35) students who are studying in a multimedia division of the Islamic University. The researcher used the experimental method according to the nature of the head. After applying statistical treatments to the criteria, the results showed a statistical indication between the experimental group before and after the trial, and the differences were in favor of the dimensional application, meaning that the program had an impact. There were statistically significant differences between the experimental group before and after the trial. The differences were in favor of the dimensional application, which also meant that the programmed impacted. A statistically significant correlation between students' grades in 3D design performance skills and their knowledge skills for 3D design .

Hassan Study (2011) aimed to investigate the effectiveness of an electronic course to develop Moodle system skills among graduate students in the Department of Education Technology at the Faculty of Education at The University of Benha. The sample of the Study was (20) students and students for the decision of the developments of educational technology, the researcher used the curriculum semi-experimentation and worked a test of achievement of his 
preparation and used a measure of motivation and achievement was prepared by Farouk Abdel Fattah Musa and the subject of experimental treatment electronic course designed and developed through Moodle Learning Management System. The results of this Study showed the effectiveness of the electronic course and its ability to develop motivation, achievement and cognitive achievement.

Mohammed's Study (2011) aimed to identify an electronic course's effectiveness to develop Moodle skills in graduate students and its impact on cognitive achievement. Using the descriptive and semi-experimental approach, the study tool consisted of a learning test and a questionnaire to identify achievement motivation. The study sample consisted of (20) students. The results showed shifts in learning methods from the teacher-oriented model, to the self-guided learning model, the Use of ICT as a source of professional development for teachers, improved teaching methods in universities, their support for technological innovations and the activation of the Role of courses. E-learning environments at the university level help grow positive trends towards their new founds, interest in using course management systems to publish courses online, and prepare students of education technology at the Faculty of Education to deal with E-learning environments.

Dahlan's Study (2012) aimed to investigate the effectiveness of a Moodle system program to enroll students in basic Education at Al-Azhar University the daily planning skills and attitudes towards the lessons. The researcher used the descriptive and semi-experimental structural Curriculum, and built the following tools: an educational test for the daily planning skills of lessons, the proposed program, to learn the program enhanced by Moodle system, and the researcher prepared a tool to measure trends for students. The study sample consisted of (60) students divided into two groups (experimental and female). The results showed no statistically significant differences between the average grades of the experimental and control group in the tribal test, the statistically significant differences between the average grades of the experimental group and the control in the dimensional test in favor of the experimental group, and the statistically significant differences between the average grades of student trends attribuTable to the Moodle-enhanced program.

\subsection{Comment on Previous Studies}

The current Study benefited from previous studies in methodology, selecting the sample, the approved tools, and the necessary statistical treatments. However, it was distinguished from previous studies in being one of the first scientific studies that dealt with the evaluation of Moodle in the light of the criteria of educational websites from the point of view of students of educational technology, which was not conducted by any previous study, within the limits of the researcher's knowledge and knowledge.

\section{Method and Procedures}

Curriculum

The researcher used the descriptive survey method to suit this type of research and is based on students' opinions in The Public Authority for Applied Education and Training in Kuwait to reach the required results. 


\section{IN Macrothink}

\section{The study community and its eyes}

The entire study community $(17,455)$ students from the Faculty of Basic Education in the General Authority for Applied Education and Training in the second semester of the 2020/2019 academic year, the Number of male students $(5,324)$ students and females $(12,131)$ students .

The researcher selected the sample of the Study of (392) students randomly from the undergraduate students in the second academic year 2020/2019, and the sample included (152) students and (240) students in the Faculty of Basic Education in the General Authority for Applied Education and Training. The researcher selected a mean sample of (20) students, who applied the study tool to them.

Table 1. Iterations and percentages by study variables

\begin{tabular}{|l|l|l|l|}
\hline & categories & Iteration & Percentage \\
\hline \multirow{3}{*}{ Gender } & male & 152 & 38.8 \\
\cline { 2 - 5 } & female & 240 & 61.2 \\
\hline & Total & 392 & 100.0 \\
\hline
\end{tabular}

\section{Study tool}

After reading the theoretical literature and the few related studies that the researcher was able to obtain, they prepared a list of criteria for evaluating Moodle site, the list consisted of (30) paragraphs, divided into five axes: (axis of Use, content axis, axis of educational value, dynamic axis, axis of vitality, axis Properties of Use). Indicators of honesty and consistency of the tool have been verified.

Believe the tool.

The authenticity of the tool was confirmed by presenting it to some arbitrators specializing in education technology and Curriculum in its initial form, ensuring the appropriateness and affiliation of the paragraphs, the integrity of their formulation, and introducing them and making formal adjustments, and taking out the questionnaire in its final form.

The stability of the study tool

To ensure the stability of the study tool, the test-retest method was verified by applying the scale, and reapplied two weeks later to a group outside the study sample consisting of (30). Then the Pearson correlation coefficient was calculated between their estimates twice.

The stability factor was also calculated in the internal consistency manner by the Cronbach's Alpha equation, and Table (2) shows the coefficient of internal consistency 


\section{Macrothink}

International Journal of Learning and Development

ISSN 2164-4063 2021, Vol. 11, No. 1

according to the Cronbach's Alpha equation and the stability of the return of the areas and the tool as a whole. These values were considered appropriate for this Study.

Table 2. Cronbach's Alpha Internal Consistency Coefficient and Realignment Stability of Fields and Total Grade

\begin{tabular}{|l|l|l|}
\hline field & Replay stability & Internal consistency \\
\hline The focus of Use & 0.86 & 0.82 \\
\hline Content Hub & 0.89 & 0.84 \\
\hline The focus of educational value & 0.91 & 0.80 \\
\hline Biocentres & 0.87 & 0.81 \\
\hline Axis of use properties & 0.89 & 0.80 \\
\hline College degree & 0.92 & 0.91 \\
\hline
\end{tabular}

\section{Statistical standard}

The Five-Year Linker ladder was adopted to correct the study tools, giving each of its paragraphs one score out of five (strongly ok, ok, neutral, disagreeable, not strongly approved) and represents digitally $(5,4,3,2,1)$ respectively. The following measure has been adopted to analyze the results:

From 1.00- 2.33 few

From 2.34 - 3.67 medium

From 3.68- 5.00 Large

And so on.

The scale was calculated by using the following equation:

$$
\frac{\text { Upper scale }(5)-\text { minimum scale }(1)}{\text { Number of categories required (3) }}=1.33
$$

Then add the answer (1.33) to the end of each category.

\section{Study procedures}

The researcher prepared this Study according to the following steps:

-The researcher prepared the theoretical framework for the Study after reading the theoretical 


\section{Macrothink}

International Journal of Learning and Development

ISSN 2164-4063

2021, Vol. 11, No. 1

literature, and identifying the variables: evaluation of Moodle site, standards of educational websites, students of education technology .

- The researcher conducted a survey of previous studies that dealt with each variable separately in Arab and foreign environments, and was obtained Arab and foreign studies related, and did not get the researcher studies of the variables combined - according to the researcher' knowledge - the Study may be the first of its kind in the State of Kuwait.

- The researcher processed the study tools and confirmed its sincerity and stability through the sample and after presenting it to a committee of arbitrators.

- After ensuring the sincerity and stability of the tools in many ways, the researcher identified the study sample and applied the tools to it.

- The researcher came up with a set of results after emptying the scans and conducting statistical analysis using appropriate statistical treatments, and then interpreted them in the light of the theoretical framework and previous studies.

Based on these findings and their interpretation, the researcher came up with a set of conclusions, made several recommendations for Use in educational and psychological work, and proposed several topics for future studies.

\section{Statistical treatment}

In the light of the Study's questions, the researcher used the appropriate statistical treatments through analysis on SPSS. The researcher used mathematical averages and standard deviations, the Cronbach's alpha internal consistency coefficient and the stability of replays and repetitions, and analyzed the quadrant contrast to show Study variables, and the Use of a Chevy method of dimensional comparisons of the effect of variables.

\section{View and discuss the results of the Study}

Question 1: What is Moodle's rating in light of educational websites' standards from the point of view of students of educational technology in Kuwait?

To answer this question, the numeracy averages and standard deviations of Moodle's rating were extracted in the light of the standards of educational websites from the point of view of students of education technology in Kuwait. The Table below shows this. 
Table 3. Computational averages and standard deviations to the degree of Moodle evaluation in light of the criteria of e-learning sites from the point of view of students of educational technology ranked downward by mathematical averages

\begin{tabular}{|c|c|c|c|c|c|c|}
\hline Rank & Number & Paragraphs & $\begin{array}{l}\text { Average } \\
\text { arithmetic }\end{array}$ & $\begin{array}{l}\text { Standard } \\
\text { deviation }\end{array}$ & $\begin{array}{l}\text { Relative } \\
\text { weight }\end{array}$ & Class \\
\hline 1 & 4 & Biocentres & 3.75 & .770 & $\% 75$ & Big. \\
\hline 2 & 3 & $\begin{array}{l}\text { The focus of } \\
\text { educational value }\end{array}$ & 3.70 & .527 & $\% 74$ & Big. \\
\hline 3 & 2 & Content Hub & 3.48 & .632 & $\% 69.6$ & Medium \\
\hline 4 & 5 & $\begin{array}{l}\text { Axis of use } \\
\text { properties }\end{array}$ & 3.47 & .716 & $\% 69.4$ & Medium \\
\hline \multirow[t]{2}{*}{5} & 1 & The focus of use & 3.46 & .678 & $\% 69.2$ & Medium \\
\hline & & College degree & 3.55 & .576 & $\% 71$ & Medium \\
\hline
\end{tabular}

Table (3) shows that the mathematical averages ranged from (3.46-3.75), where the axis of vitality came in first place significantly. The highest mathematical average of (3.75) and $71 \%$, and the axis of educational value came in second place significantly with an average of my account (3.70) and 75\%. The focus of content came with an average account average of (3.48) at $69.6 \%$, the axis of usage characteristics came in with an average of $69.4 \%$. In comparison, the axis of Use came in last place with a mathematical average of $69.2 \%$, and the average arithmetic for the tool as a whole. 3.55).

The researcher attributes the result of the current question, which came with evaluating the evaluation criteria at Moodle with a middle grade. An average calculation of (3.75) by $71 \%$, to the need of Moodle for adjustments commensurate with its educational importance in the light of the criteria, although the ratio can be generally judged as Accepted, however, there is a need to develop the site to become a high percentage to achieve the educational objectives of students. The center piece of vitality came in first place significantly and the highest mathematical average of (3.75) and $71 \%$, and the axis of educational value came in second place significantly with a mathematical average (3.70) and $75 \%$, and it seems that this result came to achieve the site attractive in both innovation in design and beauty in Images and movements, and the site may have an emotional effect that makes the user excited to visit him, the appropriateness of the design and images used in it types of service provided by the site, and contains the characteristics of wallpapers, interfaces, colors, videos, sound and image that make the site attractive to students learning, The site corresponds to the talents and abilities of students to exchange experiences, and the site enjoys innovation and modernity 
permanently, and provides an opportunity for the learner to navigate the site and delve into it, and get Information with ease, and is used effectively and works to solve technical problems during the implementation of some educational activities, Effective and dynamic participation between students and the faculty.

The rest of the axes as the content axis came with an average of (3.48) by $69.6 \%$. The axis of usage characteristics came with an average of (3.47) with a mathematical average of $(3.47 \%)$ by $69.4 \%$. In comparison, the axis of Use came in last place and the average arithmetic (3.46) by $69.2 \%$. The researcher attributes the medium result is that the site needs some modifications and development for easy Use, browsing and adding Information to the site when using it, easy Use, understanding and dealing with the site, reliability, raising interactive and technical features, security and privacy and adapting the content of the site as needed According to the user's desire for a more effective site in the light of e-learning standards and more conducive to learning and Education. The result of the current question was agreed with the Study (Badr, 2001; Lamont, 2008; Nurkhamimi, et al.,2016; Jackson \& Helms, 2008; Cahalan, 2000), the results of the current question differed with a study (Sánchez-Santamaría, et al., 2012) where the model site was highly evaluated with reference to some constraints such as training and technical problems.

The calculation averages and standard deviations of the study sample estimates were calculated on the paragraphs of each axis, as follows:

\section{First: The axis of Use}

Table 4. Computational averages and standard deviations of the paragraphs related to the axis of Use are ranked downwardly by calculation averages

\begin{tabular}{|c|c|c|c|c|c|}
\hline Rank & Number & Paragraphs & $\begin{array}{l}\text { Average } \\
\text { arithmetic }\end{array}$ & $\begin{array}{l}\text { Standard } \\
\text { deviation }\end{array}$ & Class \\
\hline 1 & 2 & $\begin{array}{l}\text { The home page contains a } \\
\text { well-classified and clear Table of the } \\
\text { site's contents }\end{array}$ & 4.14 & .896 & Big. \\
\hline 2 & 1 & $\begin{array}{l}\text { The site's objectives are clearly visible } \\
\text { to students }\end{array}$ & 3.80 & .987 & Big. \\
\hline 3 & 3 & $\begin{array}{l}\text { Easy and clear navigation between site } \\
\text { pages }\end{array}$ & 3.76 & .943 & Big. \\
\hline 4 & 6 & $\begin{array}{l}\text { Easy reading of text sat on the pages } \\
\text { of the site }\end{array}$ & 3.76 & 1.066 & Big. \\
\hline
\end{tabular}




\begin{tabular}{|l|l|l|l|l|l|}
\hline Rank & Number & Paragraphs & $\begin{array}{l}\text { Average } \\
\text { arithmetic }\end{array}$ & $\begin{array}{l}\text { Standard } \\
\text { deviation }\end{array}$ & Class \\
\hline 5 & 5 & $\begin{array}{l}\text { The site uses multiple media such as } \\
\text { sound, image and some effects }\end{array}$ & 3.01 & 1.354 & Medium \\
\hline 6 & 4 & $\begin{array}{l}\text { The pages of the site are characterized } \\
\text { by consistency and aesthetic in colors } \\
\text { and the quality of the lines }\end{array}$ & 2.27 & 1.144 & A few. \\
\hline & & The focus of Use & 3.46 & .678 & Medium \\
\hline
\end{tabular}

Table (4) shows that the arithmetic averages ranged from (2.27-4.14), where paragraph 2, which states "The home page contains a Table of the contents of the site classified well and clearly", in the first place and with a mathematical average of (4.14), while paragraph 4 and its text "distinguished" The pages of the site are consistent and aesthetic in colors and the quality of the fonts" in the last place and with a mathematical average of (2.27). The average calculation of the axis of Use as a whole was (3.46).

The researcher attributes the result in paragraph $(2,1,3,6)$ to the availability of these criteria and their Use on Moodle site, which motivates the student to use the site as an attractive element compatible with electronic educational standards and students' needs for the process of learning and Education. In contrast, the criterion (5) came with an average mathematical average of (3.01) The researcher attributed the need to modify the site in terms of the Use of multimedia such as audio and image and some effects, where it is used to integrate with Information within the framework to achieve the goal. The Use of cloud computing in site services may give many privileges in control and presentation Multimedia. Paragraph (4) came with a low score and an average calculation of (2.27). It seems that the site needs to develop the design of the site and the standards of a technical nature, which are key indicators to be adopted when designing the site. Despite its importance and the association of its indicators with the cognitive organization of the learner, it came in the order the latter is among the main criteria, due to the high burden placed on the team on site, the lack of specialists in digital design, and the loading of part of the responsibility of the material processor and uploading it to the faculty, which weakens the design, and leads to the different design of the interfaces. The current Study was agreed with a study (Najjar and Hasuna, 2016; Ashour, 2009; Hassan, 2011; Mohammed, 2011; Lamont, 2008). 


\section{Second: Content Hub}

Table 5. Computational averages and standard deviations of the content axis paragraphs are ranked downwardly by calculation averages

\begin{tabular}{|l|l|l|l|l|l|}
\hline Rank & Number & Paragraphs & $\begin{array}{l}\text { Average } \\
\text { arithmetic }\end{array}$ & $\begin{array}{l}\text { Standard } \\
\text { deviation }\end{array}$ & Class \\
\hline 1 & 11 & $\begin{array}{l}\text { Uses an appropriate way to display } \\
\text { Information to the user audience that } \\
\text { matches their level of Education }\end{array}$ & 3.89 & 1.030 & Big. \\
\hline 2 & 9 & $\begin{array}{l}\text { A direct relationship between the } \\
\text { Information displayed and the main } \\
\text { theme of the site }\end{array}$ & 3.84 & .908 & Big. \\
\hline 3 & 7 & $\begin{array}{l}\text { The Information on the site is based on } \\
\text { approved references }\end{array}$ & 3.47 & .972 & Medium \\
\hline 5 & 10 & $\begin{array}{l}\text { The site uses accurate and accurate } \\
\text { Information based on professional } \\
\text { scientific facts }\end{array}$ & 3.35 & 1.001 & Medium \\
\hline Information to convey different ideas & 2.85 & 1.377 & Medium \\
\hline Content Hub andes sufficient amounts of
\end{tabular}

Table 5 shows that the arithmetic averages ranged from (2.85-3.89), with paragraph 11 stating that "it uses an appropriate method of displaying information to the user audience that corresponds to their educational level", in first place with a mathematical average of (3.89). In contrast, paragraph 10 and its text "Sufficient amounts of information are available to transfer different ideas", in the last place and with a mathematical average of (2.85). The average calculation of the content axis as a whole was 3.48 .

The researcher attributes the result in paragraph $(11,9)$, which came largely. The rest of paragraphs $(7,8,10)$ with a medium degree, and the axis as a whole came in a medium degree to the fact that the university curriculum (courses) is printed in a paper way, which causes difficulty in calculating it among some faculty members in accordance with the criteria of good design, Or that some website designers and teachers do not have a good knowledge of how to write on the pages of the site, the way information is displayed on the website is different from the display in the pages of printed sources. Some teachers lack sufficient skills to deal with content and electronic content, divide them into small units, or 


\section{Macrothink}

choose from electronic repositories to be uploaded to websites, where a balanced team combines scientific expertise, management skills and education design. The result was agreed with a study (Najjar \& Hasuna, 2016; Afana, Habyabe, \& Saliha, 2014; Badr, 2001; Sánchez-Santamaría et al., 2012).

\section{Third: The focus of educational value}

Table 6. Computational averages and standard deviations of the paragraphs related to the axis of educational value are ranked downwardly according to calculation averages

\begin{tabular}{|c|c|c|c|c|c|}
\hline Rank & Number & Paragraphs & $\begin{array}{l}\text { Average } \\
\text { arithmetic }\end{array}$ & $\begin{array}{l}\text { Standard } \\
\text { deviation }\end{array}$ & Class \\
\hline 1 & 16 & $\begin{array}{l}\text { Opens the door for students to } \\
\text { communicate with their teachers and } \\
\text { classmates, making the learning process } \\
\text { more effective }\end{array}$ & 4.10 & .791 & Big. \\
\hline 2 & 12 & $\begin{array}{l}\text { Uses targeted educational events that } \\
\text { open up horizons for learners in the field } \\
\text { to be taught }\end{array}$ & 3.84 & .980 & Big. \\
\hline 3 & 13 & $\begin{array}{l}\text { Allows students to use the new } \\
\text { Information they learn to obtain } \\
\text { important and useful products }\end{array}$ & 3.81 & .932 & Big. \\
\hline 4 & 17 & $\begin{array}{l}\text { Provides various ways to help solve } \\
\text { technical problems, such as writing or } \\
\text { teaching during some educational } \\
\text { activities }\end{array}$ & 3.80 & 1.029 & Big. \\
\hline 5 & 14 & $\begin{array}{l}\text { Educational events on the site are } \\
\text { accompanied by clear and appropriate } \\
\text { plans for the theme of the event }\end{array}$ & 3.59 & 1.154 & Medium \\
\hline 6 & 15 & $\begin{array}{l}\text { The site allows the learner to sail and } \\
\text { delve deeper into the implementation of } \\
\text { event plans using different educational } \\
\text { resources. }\end{array}$ & 3.06 & 1.363 & Medium \\
\hline & & The focus of educational value & 3.70 & .527 & Big. \\
\hline
\end{tabular}




\section{Macrothink}

Table 6 shows that the arithmetic averages ranged from (3.06-4.10), with paragraph 16 stating that "students are allowed to communicate with their teachers and classmates, making the learning process more effective", in first place with a mathematical average of 4.10, while paragraph No. (15) The text "The site provides the learner with the opportunity to sail and go deeper into the implementation of event plans using different educational sources", in the last place with an average calculation of (3.06). The average arithmetic for the pedagogical value axis as a whole was 3.70 .

The result is due to the high availability of educational value, the effectiveness of the site in contributing to the promotion of thinking and dialogue with colleagues and teachers, the awareness of designers of the importance of the standard, and the experience of designers in applying technology in an educational context that made the site based on mostly planned practices, and to be oriented Technically, some teachers have electronic skills, although few teachers can convert the university course into computerized educational programs. The result was agreed with a study (Badr, 2001; Afana, Habyabe and Saliha, 2014; Najjar and Hasuna, 2016; Nurkhamimi, et al., 2016 Sánchez-Santamaría, et al.,2012 Lamont, 2008; The united states of The United States of The United States of The United States of The United States of The United States of The United States of The United States of Cahalan, 2000;).

\section{Fourth: The axis of vitality}

Table 7. Computational averages and standard deviations of bio axis paragraphs are ranked downwardly by arithmetic averages

\begin{tabular}{|l|l|l|l|l|l|}
\hline Rank & Number & Paragraphs & $\begin{array}{l}\text { Average } \\
\text { arithmetic }\end{array}$ & $\begin{array}{l}\text { Standard } \\
\text { deviation }\end{array}$ & Class \\
\hline 1 & 18 & $\begin{array}{l}\text { I constantly follow the daily program of } \\
\text { the college channel for the introduction } \\
\text { of educational technology available on } \\
\text { the site }\end{array}$ & 3.92 & .908 & Big. \\
\hline 2 & 19 & $\begin{array}{l}\text { The e-mail available on the site makes it } \\
\text { easy for me to communicate with those } \\
\text { who agree with me in the same talents } \\
\text { and abilities to share experiences }\end{array}$ & 3.89 & .927 & Big. \\
\hline 3 & 20 & $\begin{array}{l}\text { Students are directed to additional pages } \\
\text { within the same site or other sites }\end{array}$ & 3.81 & .982 & Big. \\
\hline & $\begin{array}{l}\text { The site is innovative and up-to-date, } \\
\text { and updates and modifications to the } \\
\text { Information and content available on the }\end{array}$ & 3.39 & 1.070 \\
\hline
\end{tabular}




\begin{tabular}{|l|l|l|l|l|l|}
\hline Rank & Number & Paragraphs & $\begin{array}{l}\text { Average } \\
\text { arithmetic }\end{array}$ & $\begin{array}{l}\text { Standard } \\
\text { deviation }\end{array}$ & Class \\
\hline & & site permanently & & & \\
\hline & Biocentre & 3.75 & .770 & Big. \\
\hline
\end{tabular}

Table (7) shows that the arithmetic averages ranged from (3.39-3.92), with paragraph 18 stating that "I constantly follow the daily program of the college channel for the introduction of the educational technology material available on the site", in the first place and with a mathematical average of (3.92). In contrast, the paragraph came Number (21) and its text "The site enjoys innovation and modernity, and updates and modifications to the information and content available on the site permanently" in the last place and with a mathematical average of (3.39). The computational average of the bio-axis as a whole was 3.75 .

The results showed that the bio-axis was largely present and that computational averages ranged from (3.39-3.92) to the mathematical average of the bio axis as a whole (3.75). This shows that the site performs the tasks assigned to it properly, the technical support and expertise of the site administrators in effectively designing the interaction tools, attention to interactive links, which cause effectiveness and encouragement for students to learn, and the interest of the site administrators in updating Renewal and permanent modifications to Information and content. The current Study was agreed with the Study (Najjar and Hasuna, 2016; Mohammed, 2011; Hassan, 2011; Bremer \& Brayant, 2005 Sánchez-Santamaría, et al., 2012; Nurkhamimi et al., 2016;).

\section{Fifth: The axis of the characteristics of Use}

Table 8. Computational averages and standard deviations of paragraphs related to the axis of usage properties are ranked downwardly by calculation averages

\begin{tabular}{|l|l|l|l|l|l|}
\hline Rank & Number & Paragraphs & $\begin{array}{l}\text { Average } \\
\text { arithmetic }\end{array}$ & $\begin{array}{l}\text { Standard } \\
\text { deviation }\end{array}$ & Class \\
\hline 1 & 29 & Easy access to and exit of the site & 4.03 & .893 & Big. \\
\hline 2 & 22 & $\begin{array}{l}\text { Takes into account the logical } \\
\text { sequence and sequence of lessons }\end{array}$ & 3.89 & 1.000 & Big. \\
\hline 3 & 23 & $\begin{array}{l}\text { Encourages students to cooperate } \\
\text { and work together }\end{array}$ & 3.86 & .971 & Big. \\
\hline 4 & 27 & $\begin{array}{l}\text { Provides enriching activities for } \\
\text { fast-learning students }\end{array}$ & 3.78 & .907 & Big. \\
\hline
\end{tabular}




\begin{tabular}{|c|c|c|c|c|c|}
\hline Rank & Number & Paragraphs & $\begin{array}{l}\text { Average } \\
\text { arithmetic }\end{array}$ & $\begin{array}{l}\text { Standard } \\
\text { deviation }\end{array}$ & Class \\
\hline 5 & 28 & $\begin{array}{l}\text { Print some results, activities, or } \\
\text { lessons }\end{array}$ & 3.76 & 1.042 & Big. \\
\hline 6 & 24 & $\begin{array}{l}\text { Provides the student with a } \\
\text { summary of his scientific } \\
\text { performance }\end{array}$ & 3.74 & 1.185 & Big. \\
\hline 7 & 25 & $\begin{array}{l}\text { Allows the student to choose to } \\
\text { return to review certain parts of } \\
\text { certain lessons }\end{array}$ & 3.04 & 1.286 & Medium \\
\hline 8 & 30 & $\begin{array}{l}\text { The site helps me express my } \\
\text { talents and abilities by } \\
\text { participating in student creations. }\end{array}$ & 2.97 & 1.329 & Medium \\
\hline 9 & 26 & $\begin{array}{l}\text { The site reduces the student's } \\
\text { dependence on the teacher in the } \\
\text { education process }\end{array}$ & 2.17 & 1.218 & Medium \\
\hline & & Axis of use properties & 3.47 & .716 & Medium \\
\hline
\end{tabular}

Table 8 shows that the arithmetic averages ranged from (2.17-4.03), where paragraph 29 , which states "easy access to and exit of the site", came in first place with a mathematical average of (4.03), while paragraph no. (26) and text "The site reduces the student's dependence on the teacher in the education process is last place with an average of 2.17 . The average arithmetic of the axis of properties of the Use as a whole (3.47).

This result is due to the nature of the standard and its indicators as it does not need the depth of knowledge of the site designer, or the organization to highlight it on the site. It represents key indicators to be adopted when designing the site, and to contain the site to the operating requirements, the strength of the site's reference and Information, and the ability of students to Evaluate the material according to their abilities. The current result was agreed with a study (Najjar \& Hasuna, 2016; Jackson \& Helms, 2008).

Question 2: The question states: "Are there statistically significant differences $(=0.05)$ in the degree to which Moodle is evaluated in the light of the criteria of educational websites from the point of view of students of educational technology in Kuwait attribuTable to the Gender variable"?

To answer this question, the mathematical averages and standard deviations were extracted to 
the point of evaluating Moodle in the light of the criteria of educational websites from the point of view of students of educational technology in Kuwait according to the variable of Gender, and to show the statistical differences between the mathematical averages have been Use the test, and the Tables below illustrate this

Table 9. Arithmetic averages, standard deviations and the " $\mathrm{T}$ " test of the impact of Gender on Moodle's rating in light of the standards of educational websites from the point of view of students of education technology in Kuwait

\begin{tabular}{|c|c|c|c|c|c|c|c|}
\hline Category & gender & Number & $\begin{array}{l}\text { Average } \\
\text { arithmetic }\end{array}$ & $\begin{array}{l}\text { Standard } \\
\text { deviation }\end{array}$ & $\begin{array}{l}\text { Value } \\
\text { "t" }\end{array}$ & $\begin{array}{l}\text { Degrees } \\
\text { of } \\
\text { freedom }\end{array}$ & $\begin{array}{l}\text { Statistical } \\
\text { significance }\end{array}$ \\
\hline \multirow{2}{*}{$\begin{array}{l}\text { The focus } \\
\text { of Use }\end{array}$} & male & 152 & 3.51 & .612 & 1.243 & 390 & .215 \\
\hline & Female & 240 & 3.42 & .715 & & & \\
\hline \multirow{2}{*}{$\begin{array}{l}\text { Content } \\
\mathrm{Hub}\end{array}$} & male & 152 & 3.51 & .608 & .831 & 390 & .406 \\
\hline & Female & 240 & 3.46 & .647 & & & \\
\hline \multirow{2}{*}{$\begin{array}{l}\text { The focus } \\
\text { of } \\
\text { educational } \\
\text { value }\end{array}$} & male & 152 & 3.71 & .509 & .400 & 390 & .689 \\
\hline & Female & 240 & 3.69 & .538 & & & \\
\hline \multirow[t]{2}{*}{ Biocentres } & male & 152 & 3.78 & .674 & .553 & 390 & .581 \\
\hline & Female & 240 & 3.74 & .826 & & & \\
\hline \multirow{2}{*}{$\begin{array}{l}\text { Axis of use } \\
\text { properties }\end{array}$} & male & 152 & 3.54 & .666 & 1.620 & 390 & .106 \\
\hline & Female & 240 & 3.42 & .744 & & & \\
\hline \multirow{2}{*}{$\begin{array}{l}\text { College } \\
\text { degree }\end{array}$} & male & 152 & 3.60 & .530 & 1.220 & 390 & .223 \\
\hline & Female & 240 & 3.52 & .603 & & & \\
\hline
\end{tabular}




\section{Macrothink}

International Journal of Learning and Development

ISSN 2164-4063

2021, Vol. 11, No. 1

Table (9) shows no statistically significant differences $(=0.05)$ attribuTable to the effect of Gender in all axes and the overall degree. The current result is that students are aware of the importance of the site and can evaluate it in the light of electronic educational standards, the ability to deal with information, content, content and usage characteristics, reliability and usage needs, and the educational value that must be available within Standards indicators at Moodle.' This finding was agreed with a study (Hassan, 2011; Jackson \& Helms, 2008 Cahalan, 2000).

\section{References}

Abdul Majid, Sadiq (2008). A proposed program in e-learning using open-source free software and its impact on designing and production skills for e-math lessons and the trend towards e-learning among student teachers. Journal of the Faculty of Education, Mansoura University, Egypt, 66(2), 336-385.

Abu Hassan, Mohammed Taya Ibrahim (2010). Online e-learning management systems. $\begin{array}{lllll}\text { Retrieved on } & 27 & \text { March } & \text { 2013, from }\end{array}$ http://www.lrc-online.net/library/wp-content/uploads/2010/06/mm.pdf

Abu khtwa, A., \& Abdul, M. (2010). Principles of e-course design derived from learning theories and educational applications. A study presented to the conference "The Role of E-Learning in The Promotion of Knowledge Societies", held at Zain E-Learning Center, University of Bahrain, from 6-8/4/2010.

Achour, H., \& Ben Abdesslam, W. (2012). An Evaluation of Arabic language learning websites. International Conference on Education and eLearning Innovations (ICEELI). https://doi.org/10.1109/ICEELI.2012.6360683

Afona, S. A., \& Salha, S. (2014). Evaluation of Al-Najah University's experience in employing the Electronic Learning Management System (Model) in the in-service science rehabilitation program. Hebron University Research Journal, 9(2), 95-117.

Ahmed, H., \& Saeed, F. (2014). Evaluation of electronic courses at the Open University of Sudan in light of electronic courses' quality standards. Palestinian Open Education Review, Palestine, 4(8), 126-87.

Al-Ghamdi, A. B. M. (2009). The importance of the overall quality standards for Islamic education teachers at the primary level from specialists' point of view (Unpublished Master's thesis in Curriculum and Teaching Methods, Aman Al-Qura University, Saudi Arabia).

Al-Ghribi, Y. B. M. B. A. (2009). The impact of teaching using electronic classrooms in three images (interactive, collaborative, integrative) on fifth graders in mathematics (Unpublished master's thesis in mathematics curriculum and teaching mathematics methods, Faculty of Education, Um al-Qura University).

Al-Hindawi, O. (2005). The effectiveness of a proposed multimedia program in developing the skills and innovative thinking of students in the Internet's educational applications (Unpublished PhD, Faculty of Education, Al-Azhar University). 
Al-Jarf, R. S. (2004). The extent to which faculty members at Saudi universities use e-learning: reality and aspirations. Record the symposium proceedings on the development of faculty at Saudi universities, Faculty of Education, King Saud University, Riyadh.

Al-Khaznadar, N. (2006). Evaluating the content of the mathematics books for the basic stage in the light of Brunner's theory. The first scientific conference "The Palestinian experience in the preparation of reality and aspirations curricula", December 19-20, Faculty of Education, Al-Aqsa University, Gaza, p. 428-452.

Al-Luqani, A., \& Al-Jamal, A. (2003). Dictionary of educational terms known in curricula and teaching methods (3rd ed.). Cairo: The World of Book for Publishing and Distribution.

Al-Mutairi, B. B. M. (2008). The effectiveness of using educational software on first-graders in mathematics (Unpublished master's thesis in mathematics curriculum and teaching mathematics methods, Faculty of Education, Um al-Qura University).

Al-Najjar, H., \& Hasuna, I. (2016). Evaluation of the Educational Reaad site of the Ministry of Education and Higher Education in Palestine according to specific criteria. Al-Aqsa University Journal, Humanities Series, 20(1), 67-102. https://doi.org/10.12816/0026648

Al-Omari, A., \& Falata, F. (2014). Design a website to learn and evaluate the Qur'an in light of the specific criteria. The Future of Arab Education, Egypt, 21(88), 107-188.

Al-Omari, M. K.(2002). Evaluation of the Book of Islamic Education for the 10th grade from the perspective of Islamic education teachers in Irbid province (Unpublished Master's thesis in Educational Sciences, Al-Bayt University, Mafraq).

AlRoobaea, R., Al-Badi, A., \& Mayhew, P. (2013). A Framework for generating domain-specific heuristics for evaluating online educational websites. International Journal of Information Technology \& Computer Science (IJITCS), 8(2), 75-84. https://doi.org/10.2139/ssrn.2407440

Al-Saleh, B. B. A. (2005). E-learning and educational design: a partnership for quality. Research presented to the 10th Scientific Conference of the Egyptian Society for Electronic Learning Technology and Comprehensive Quality Requirements, 5-7/7/2005, Faculty of Education, Ain Shams University, Egypt.

Al-Shahrani, N. B. A. N. (2009). The demands of using e-learning to teach natural sciences in higher Education from specialists' point of view (Unpublished Doctoral Thesis, Department of Curriculum and Teaching Methods, Faculty of Education, Um al-Qura University, Saudi Arabia).

Al-Sunbal, A. A. A. (2001). Quality control principles and procedures. Magazine for Public Education, (48), Arab Organization for Education, Education and Science.

Amasha, M. A. R. (2009). E-learning and web 2.0. Informatics Magazine, Saudi Ministry of Education, (24): 1-16.

Andrews, S. (2001) Evaluation of website: www.doe.state.in.us chartered for Indiana 
clearinghouse for citizenship and character education. ERIC Number: ED458637. Retrieved from http://eric.ed.gov/?id=ED458637

Ashour, M. I. N. (2009). Moodle's effectiveness in acquiring 3D design skills among Students of Education Technology at the Islamic University (Unpublished master's thesis in curriculum and education technology, Faculty of Education, Islamic University, Gaza, Palestine).

Badr, M. (2001). Use the Internet to teach the statistics unit to first-grade high school students. 13th Scientific Conference: Curricula and Contemporary Cognitive and Technological Revolution, July 25-24, 2001: Guest House- Ain Shams University, Volume 1, Cairo: Egyptian Society of Curriculum and Teaching Methods.

Bantjes, L., \& Cronje, J. (2000). An analysis of criteria for the evaluation of educational web sites. South African Journal of Higher Education, 14(1), 121-129.

Bhatia, R. (2011). Features and effectiveness of e-learning tools. Global Journal of Business Management and Information Technology, 1(1), 1-7.

Bou Jahajoh, Y., \& Harb, S. (2013). The educational website's horizontal and vertical design is effective in acquiring front page skills, self-learning, and visual thinking for teachers. Journal of the Open University of Jerusalem for Research and Studies, 1(1), 163-206.

Bremer, D., \& Bryant, R. (2005). A Comparison of two learning management Systems: Moodle vs Blackboard. Proceedings of the 18th Annual Conference of the National Advisory Committee on Computing Qualifications.

Dos Santos, B. L., \& Wright, A. L. (2001). Internet-supported management education. Information Services \& Use, 21(2), 53-64. https://doi.org/10.3233/ISU-2001-21202

Burgess, G. (2001). Technology in the classrooms: New designs for learning. Paper presented at the international conference on technology and Education, Tallahassee, FL. Retrieved from www.icte.org/T01_Library/T01_217.pdf

Cahalan, K. (2000). Design of Electronic Classroom Graphical User Interface: Nova Southeastern University's Multimedia Electronic Classroom projects (Thesis (ph. D) Nov Southeastern University: P253).

Canada, M. (2000). Students as seekers in online courses. New Directions for Teaching and Learning, (84), 35-40. https://doi.org/10.1002/t1.845

Clewley, N., Chen, Y., \& Liu, X. (2011). Mining learning preferences in web-based instruction: holists vs. serialists. Educational Technology \& Society, 14(4): 266-277.

Dahlan, O. (2012). The effectiveness of a program enhanced by moodle system to give students of basic Education at Al-Azhar University the skills of daily planning of lessons and their attitudes towards it (Unpublished Master's thesis, Al-Azhar University, Gaza).

Filmban, G. (2012). Basic criteria for evaluating faculty websites. Journal of the Faculty of Education, Al-Azhar University, 2(150), 284-336. 
Hadjerrouit, S. (2010). Developing web-based learning resources in school education: A user-centered approach. Interdisciplinary Journal of E-Learning and Learning Objects (IJELLO), 6(24): 115-135. https://doi.org/10.28945/1172

Hammad, S. A. (2011). The quality of the content of Islamic education books for the higher basic stage in Palestine in light of the content's standards of quality and organization. Research submitted to the National Conference on Educational Evaluation, Ramallah.

Hasan, L. (2014). Evaluating the usability of educational websites based on students' preferences of design characteristics. International Arab Journal of e-Technology, 3(3), 179-193.

Hassan, N. E. S. (2011). An electronic course's effectiveness to develop Moodle skills in graduate students and its impact on cognitive and motivational achievement. Research presented at the second international e-learning conference held in February 2011 in Riyadh.

Hassanein, M. (2009). Evaluating the content of the Website of the General Authority for Adult Education on the Internet in light of achieving its objectives with a proposed vision for its development. Studies in curriculum and teaching methods, Egypt, (144), 191-134.

Hopkins, J. (2010). Synchronous vs. asynchronous distance learning activities. Hopkins University School of Education, Center for Technology in Education. Retrieved from HTTPs:/prezi.com/mkc3n1s2cybq/asynchronous-andsynchronous/

Jackson, M. J., \& Helms, M. M. (2008). Student perceptions of hybrid courses: Measuring and interpreting quality. Journal of Education for Business, 84(1), 7-12. https://doi.org/10.3200/JOEB.84.1.7-12

Khalifa, H. (2008). Employ web 2.0 technologies in the service of Education. Riyadh: King Saud University.

Khalil, H. (2008). List of e-learning quality standards for online course design (Unpublished Master's Thesis, Mansoura University).

King, L., \& Leroy, B. (2014). Developing an online learning community in industrial law. critical perspectives on educational technology. Retrieved from http://ascilite2014.otago.ac.nz/files/concisepapers/235-King.pdf

Knowlton, D. (2000). A theoretical framework for the online classroom: A defense and delineation of a student-centered pedagogy. New Directions for Teaching and Learning, (84), 5-14. https://doi.org/10.1002/t1.841

Kozma, B. (2003). Technology and classroom practices: an international study. Journal of Technology in Education, 36(1), 1-14. https://doi.org/10.1080/15391523.2003.10782399

Lamont, L. (2008). E-Learning: Options for Delivery. Copyright of KM World, A PUBLICATION OF INFORMATION TODAY, INC. TEL. 207.236.8524 FAX. 207.236.6452 www.kmworld.Com e-mail, editor@kmworld.com. 18 BAYVIEW LANDING (POB 1358) CAMDEN, ME 04843. Volume 17 Issue 5: Pp 22-30. 


\section{Macrothink Institute ${ }^{\mathrm{TM}}$}

Liu, L. (2007). An intermediate effect between the quality of web-based learning applications and student learning. International Journal of Technology in Teaching and Learning, 3(2), $29-46$.

McKimm, J., Jollie C., \& Cantillon. P (2003). Web based learning. BMJ: British Medical Journal, 326(7394), 870-873. https://doi.org/10.1136/bmj.326.7394.870

Mohamed, H. (2014). Evaluation of the e-book in Arabic for the third grade of primary year in light of the quality standards. Arab Studies in Education and Psychology, Saudi Arabia, 2(45), 11-72.

Mohamed, N. E. S. (2011). An electronic course's effectiveness to develop the skills of using the Moodle system among graduate students and its impact on cognitive achievement and motivation of achievement (Unpublished Master's Thesis, Faculty of Education, Binha University).

Mohammed, W., \& Abdul Azim, R. (2011). Curriculum design (1st ed.). Amman: Al-Sala'a Publishing, Distribution and Printing House.

Nurkhamimi, Z., Rozhan, I., \& Ahmad, F. (2016). Moodle as an ODL teaching tool: A Perspective of Students and Academics. Electronic Journal of e-Learning, 14(4), 282-289.

Riel, M., \& Fulton, K. (2001). The Role of technology in supporting learning communities. Phi Delta Kappan, 82(7), 518-523. https://doi.org/10.1177/003172170108200708

Saba, K. (2005). Hybrid model for eLearning at virtual university of Pakistan. The Electronic Journal of eLearning, 3(1), 67-76.

Sánchez- Santamaria, J., Ramos, F. J., \& Sánchez-Antolini. (2012). The Student's Perspective: Teaching Usages of Moodle at University. Proceedings of ICERI2012 Conference 19th-21 ${ }^{\text {st }}$, November 2012, Madrid, Spain.

Schwier, R. (2001). Evaluation of educational websites. EDCMM 802.6. Retrieved from http://etad.usask.ca/802papers/bokcaisse/bokcaisse.pdf

Shawk, M., \& Malik, M. (2001). The 21st century teacher chose, prepared, developed (in the light of The Islamic Orientations), Cairo: Arab Thought House.

Trujillo, H. (2008). Benefits and challenges for the online learner. educational benefits of online learning. Thomas Jefferson University. Retrieved from http://www.strayer.edu/online_benefits

Weaver, D. (2008). Academic and student use of a learning management system: Implications for quality. Australasian Journal of Educational Technology, 24(1), 30-41. https://doi.org/10.14742/ajet.1228

Wisker, B. (2000). Assessing for Learning in English studies: some innovative practices. Teaching in higher Education, 2(2), 22-47. https://doi.org/10.1080/1356251970020203 


\section{Macrothink}

International Journal of Learning and Development

ISSN 2164-4063 2021, Vol. 11, No. 1

\section{Copyright Disclaimer}

Copyright for this article is retained by the author(s), with first publication rights granted to the journal.

This is an open-access article distributed under the terms and conditions of the Creative Commons Attribution license (http://creativecommons.org/licenses/by/4.0/). 